\title{
Open educational resources: expanding equity or reflecting and furthering inequities?
}

\section{George Veletsianos ${ }^{1}$ (D)}

Accepted: 1 October 2020 / Published online: 7 October 2020

(c) Association for Educational Communications and Technology 2020

\begin{abstract}
In this paper I argue that open educational resources (OER), such as open textbooks, are an appropriate and worthwhile response to consider as colleges and universities shift to digital modes of teaching and learning. However, without scrutiny, such efforts may reflect or reinforce structural inequities. Thus, OER can be a mixed blessing, expanding inclusion and equity in some areas, but furthering inequities in others.
\end{abstract}

Keywords Open educational resources $\cdot$ Equity $\cdot$ Inclusion $\cdot$ Open textbooks

As part of the "shifting to digital" special issue, this paper is in response to Hilton (2016). I argue that open educational resources (OER), such as open textbooks, can expand equity and inclusion, but without scrutiny, they may reflect or reinforce, and thus expand, structural inequities.

OER are defined as "teaching, learning, and research resources that reside in the public domain or have been released under an intellectual property license that permits their free use and repurposing" (Hewlett 2017). Hilton (2016) synthesized the existing literature to examine outcomes associated with instances in which OER replaced commercial textbooks. He reported two major findings. First, students generally performed better when using OER compared to commercial textbooks. The use of OER was not associated with decreases in learning. Second, OER were generally perceived by faculty and students to be as good as, if not better than, traditional textbooks. While this research faces some limitations acknowledged by the author much research since then continues to affirm the author's original findings (e.g., Clinton and Khan 2019; Hilton 2020).

George Veletsianos

george.veletsianos@royalroads.ca

1 Royal Roads University, 2005 Sooke Road, Victoria, BC V95B 5Y2, Canada 


\section{What is the value of OER for inclusion and equity?}

The pandemic caused by COVID-19 has forced educational institutions to shift to digital modes of teaching and learning. This new environment includes a mode of education that is unfamiliar to many; it also encompasses threats and uncertainties surrounding public health, intensifying socioeconomic and racial strife, and an escalating economic crisis.

While the high cost of commercial textbooks was burdensome for higher education students prior to the pandemic (Jenkins et al. 2020), the impacts of such costs in the challenging environment that students face today are magnified. A survey that gathered data in April-May 2020 in the United States for instance, found that nearly $60 \%$ of around 38,000 student respondents faced food insecurity, housing insecurity, and homelessness (Goldrick-Rab et al. 2020). The high costs of commercial textbooks encompass significant educational burdens as well. When students do not have access to texts from the first day of the course-due to delaying/avoiding purchasing textbooks or seeking older editions of books - outcomes may suffer (e.g., Ozdemir and Hendricks 2017).

Significantly, these issues have disproportionate impacts on certain student populations, which is one of the reasons that Lambert (2018) encourages researchers and practitioners to view open education, OER, and openness as social justice issues. Low-income students, students of color, and historically underserved students in general may feel the hardships of high textbook prices more than others (e.g., Jenkins et al. 2020). When Goldrick-Rab et al., (2020) find a gap of $19 \%$ in basic needs insecurity between students identifying as White or Caucasian and students identifying as Black or African American, and Frenette et al. (2020) show that over the next 5 years they expect the pandemic to lead to greater potential financial losses for women than men post-secondary graduates in Canada, it becomes clear that the impacts of high textbook prices will continue having greater impacts on some students more than others.

\section{What may be some practical solutions?}

Hilton's (2016) research supports the widespread use of OER in higher education. In the immediate and post-pandemic era higher education, individual faculty members should consider transitioning from commercial to open textbooks. Instructional designers could support faculty in implementing OER and open practices (c.f. Morgan 2019). Libraries and Centers of Teaching and Learning could offer professional development in this area and advocate for such practices as the adoption of open textbooks and open homework systems (c.f. Okamoto 2013). Such efforts should go beyond individual action: Departments, colleges, and institutions, could devise policies to support, incentivise, and reward adoption of OER and open practices (e.g., Mays 2017).

\section{Limitations, constraints, and future suggestions}

While openness often assumes equity and justice, higher education faces numerous systemic injustices that cannot be solely addressed by OER adoption (Bayne et al. 2015; Edwards 2015; Veletsianos and Kimmons 2012). If we are not mindful, the creation and use of OER could not only reflect inequities but reinforce them as well. Hilton's (2016) 
synthesis focuses on efficacy and perceptions, overlooking issues of equity beyond economic maldistribution (c.f. Cox et al. 2020). A critical and equity-seeking adoption and examination of OER materials is necessary in order for practitioners and researchers to further dismantle some of the structural inequities that OER may reproduce. For instance:

- By asking Who creates OER? we may be able to examine the systemic structures that (dis)empower certain individuals from creating openly licensed materials. Will we discover, for example, that OER are predominantly authored by men reflecting the disparate publishing rates that we observe within educational technology journals (e.g., Scharber et al. 2019)? What steps should we take, if, for instance, we discover that a disproportionate amount of OER are produced by tenured white professors and we lack OER authored by scholars of colour?

- By asking Who is and who is not represented in OER and Are individuals' representations in OER appropriate and empowering? we may begin to examine whether OER offer broad, diverse, and accurate representations. One has to pause and question the value of OER that are associated with higher outcomes if, for instance, they marginalize or ignore people who identify as LGBTQ2+ (see Subramony 2018).

- By asking Who is cited in OER, and which forms of knowledge are reproduced in OER? we may begin engaging with the politics of citation (Mott and Cockayne 2017). Who is cited and included, and who is not cited and excluded? For instance, what will we find if we examine whether OER cite women of color and whether they cite them in comparative rates and meaningful ways to others? What if we find, say, that OER disproportionately cite Anglo- or US-centric perspectives?

These are important questions to ask. Significantly, questions of social justice, equity, and inclusion should be asked not just of OER, but of commercial textbooks as well (e.g., Wood et al. 2020). You and I should also ask these questions of our own research, teaching, and institutions. We should ask whether our curricular include broad and diverse voices, and whether those voices are integrated in meaningful and substantive ways in our research. Our efforts for more equitable and inclusive futures need to address not just other people's OER, but also our own contexts.

Acknowledgements This work was supported by a grant from the Canada Research Chairs and Social Sciences and Humanities Council to the author. The support of the Commonwealth of Learning Chairs program is also acknowledged.

\section{Compliance with ethical standards}

Conflict of interest The authors report no potential conflicts of interest.

Research involving human participants and animals This research does not involve human participants or animals.

Informed consent This is a theoretical paper and does not involve human participants.

\section{References}

Bayne, B., Knox, J., \& Ross, J. (2015). Open education: The need for a critical approach. Learning, Media and Technology, 40(3), 247-250. 
Clinton, V., \& Khan, S. (2019). Efficacy of open textbook adoption on learning performance and course withdrawal rates: A meta-analysis. AERA Open, 5(3), 1-20. https://doi.org/10.1177/233285841987221 2.

Cox, G., Masuku, B., \& Willmers, M. (2020). Open textbooks and social justice: Open educational practices to address economic, cultural and political injustice at the University of Cape Town. Journal of Interactive Media in Education, 2020(1), 2. https://doi.org/10.5334/jime.556.

Edwards, R. (2015). Knowledge infrastructures and the inscrutability of openness in education. Learning, Media and Technology, 40(3), 251-264.

Frenette, M., Handler, T., \& Messacar, D. (2020). Potential earnings losses among high school and postsecondary graduates due to the COVID-19 economic downturn. (Catalogue number 11-626-X2020012-No. 114). Statistics Canada. Retrieved July 31, 2020, from https://www150.statcan.gc.ca/ n1/pub/11-626-x/11-626-x2020012-eng.pdf.

Hewlett (2017). Retrieved July 22, 2020, from https://www.hewlett.org/strategy/open-educational-resou rces/.

Hilton, J. (2016). Open educational resources and college textbook choices: A review of research on efficacy and perceptions. Educational Technology Research and Development, 64(4), 573-590.

Hilton, J. (2020). Open educational resources, student efficacy, and user perceptions: A synthesis of research published between 2015 and 2018. Educational Technology Research and Development, 68(3), 853-876.

Goldrick-Rab, S., Coca, V., Kienzl, G., Welton, C. R., Dahl, S., \& Magnelia, S. (2020). \#RealCollege during the pandemic: New evidence on basic needs insecurity and student well-being. The Hope Center. Retrieved from https://hope4college.com/wp-content/uploads/2020/06/Hopecenter_RealCollegeDuri ngthePandemic.pdf

Jenkins, J. J., Sánchez, L. A., Schraedley, M. A. K., Hannans, J., Navick, N., \& Young, J. (2020). Textbook broke: Textbook affordability as a social justice issue. Journal of Interactive Media in Education. https ://doi.org/10.5334/jime.549.

Lambert, S. R. (2018). Changing our (dis)course: A distinctive social justice aligned definition of open education. Journal of Learning for Development, 5(3), 225-244.

Mays, T. (2017). Mainstreaming use of open educational resources (OER) in an African context. Open Praxis, 9(4), 387-401.

Morgan, T. (2019). Instructional designers and open education practices: Negotiating the gap between intentional and operational agency. Open Praxis, 11(4), 369-380.

Mott, C., \& Cockayne, D. (2017). Citation matters: Mobilizing the politics of citation toward a practice of 'conscientious engagement'. Gender, Place \& Culture, 24(7), 954-973.

Okamoto, K. (2013). Making higher education more affordable, one course reading at a time: Academic libraries as key advocates for open access textbooks and educational resources. Public Services Quarterly, 9(4), 267-283.

Ozdemir, O., \& Hendricks, C. (2017). Instructor and student experiences with open textbooks, from the California open online library for education (Cool4Ed). Journal of Computing in Higher Education, 29(1), 98-113.

Scharber, C., Pazurek, A., \& Ouyang, F. (2019). Illuminating the (in) visibility of female scholars: A gendered analysis of publishing rates within educational technology journals from 2004 to 2015. Gender and Education, 31(1), 33-61.

Subramony, D. P. (2018). Not in our journals: Digital media technologies and the LGBTQI community. TechTrends, 62(4), 354-363.

Wood, S., Henning, J. A., Chen, L., McKibben, T., Smith, M. L., Weber, M., et al. (2020). A scientist like me: Demographic analysis of biology textbooks reveals both progress and long-term lags. Proceedings of the Royal Society B, 287(1929), 20200877.

Veletsianos, G., \& Kimmons, R. (2012). Assumptions and challenges of open scholarship. The International Review Of Research In Open And Distance Learning, 13(4), 166-189.

Publisher's Note Springer Nature remains neutral with regard to jurisdictional claims in published maps and institutional affiliations.

George Veletsianos PhD is Professor and Canada Research Chair in Innovative Learning and Technology at Royal Roads University. His research examines online and flexible learning, and people's experiences of and practices in digital learning environments. 